Portland State University

PDXScholar

\title{
The Impact of Vote by Mail on Native American Turnout
}

Nathaniel J. Torry-Schrag

Portland State University

Follow this and additional works at: https://pdxscholar.library.pdx.edu/honorstheses

Part of the Political Science Commons

Let us know how access to this document benefits you.

\section{Recommended Citation}

Torry-Schrag, Nathaniel J., "The Impact of Vote by Mail on Native American Turnout" (2020). University Honors Theses. Paper 923.

https://doi.org/10.15760/honors.945

This Thesis is brought to you for free and open access. It has been accepted for inclusion in University Honors Theses by an authorized administrator of PDXScholar. Please contact us if we can make this document more accessible: pdxscholar@pdx.edu. 
The Impact of Vote by Mail on Native American Turnout

by

Nathaniel J. Torry-Schrag

An undergraduate honors thesis submitted in partial fulfillment of the requirements for the degree of

Bachelor of Arts

in

University Honors

and

Political Science

Thesis Adviser

Dr. Richard A. Clucas

Portland State University

2020 


\begin{abstract}
When Vote by Mail was fully implemented by the state of Oregon in 2000, it quickly became the subject of study by the Political Science community. While there is not yet an academic consensus about the impact of vote by mail, its growing popularity is undeniable. Mail voting has now been fully adopted in four states, with several others extensively offering mail ballots as an alternative to in-person voting. As this form of convenience voting spreads across the county, it is important to once again try to determine its impacts. This study examines a voting group often overlooked by academic research: Native Americans. With states like Arizona and Montana already utilizing mail ballots at high rates and both having significant Native American populations, it is not unrealistic to imagine the Native vote being impacted by even further expansion of full Vote By Mail. Using the Warm Springs Indian Reservation, located in northcentral Oregon, as a case study, this research project intended to compare voter turnout before and after Vote By Mail implementation on the reservation, as well as to compare relative change between Native American and non-Native American voters. Unfortunately, government office closures caused by the COVID-19 pandemic rendered it impossible to complete that statistical analysis. This article concludes with a call for additional research, given the importance of this under-researched topic.
\end{abstract}

\title{
Introduction
}

How elections are conducted is foundational to any democracy. Previous study on the impact of Vote by Mail (VBM) has focused on turnout generally. While studies have used voter files to try and determine voter characteristics, no study has been able to isolate particular demographic groups for study. This article explains how one could replicate Southwell and Burchett's (2000) methodology and apply it to the Warm Springs Reservation, testing the new hypothesis that Vote By Mail has had the effect of increasing Native American turnout. In addition to the academic contribution such a study offers, this research has important real-world applications. Not only are finding solutions to low Native American political participation important, but amidst the global COVID-19 pandemic VBM is being thrust to the forefront of political debates. The need for study is not just necessary, but urgent. 


\section{Vote By Mail}

\section{Historical Overview}

The practice of conducting elections by mail has a substantial history in Oregon. In 1981, the Oregon State legislature approved a test of VBM in local contests, making this alternative voting method available upon the discretion of county officials for county - and district-wide contests. The positive results - a combination of receptive public feedback and solid voter turnout - led to the legislature making this arrangement permanent and expanding VBM to statewide special elections. Efforts to establish a full VBM system (as opposed to the limitation to local and special elections) were shot down several times, with one bill passed by both chambers of the state legislature but ultimately vetoed by the Democratic governor.

Nevertheless, in January 1996, the Beaver State became the first in the nation to hold a general election for a federal office fully by mail. Oregon Secretary of State Phil Keisling, an ardent supporter of VBM, had the authority to dictate the method of voting for a special election for U.S. Senate, to fill the seat vacated by GOP Sen. Bob Packwood. Keisling used this opportunity to implement a first-of-its-kind election. This choice concerned many, including fellow Democrats who believed it would cost them the contest. With a surprise victory by Democrat Ron Wyden, the vote by mail movement gained traction within progressive communities as their concerns that VBM would boost Republican turnout had not come to fruition. After several more years of unsuccessful legislative efforts, supporters used Oregon's initiative process to put statewide VBM on the ballot in 1998. The ballot measure proved VBM's overwhelming popularity, passing with over 75 percent of the vote (Oregon Secretary of State, 2007). 
Oregon's success story has led to adoption of vote by mail systems in several other states. Washington transitioned to a VBM system in 2011, with Colorado and Hawaii following suit in 2013 and 2019 respectively (McAvoy 2019). In addition to the three states that have subsequently adopted full VBM, several other states use mail ballots at increasingly high rates. States like California utilize absentee voting for close to half of all ballots, and the Republicandonimated state of Utah uses VBM in all but one of its 29 counties, an exception to the pattern of VBM adoption taking place in Democratic controlled states (Thompson, et al 2020). With this form of voting on a trajectory toward wider use, the topic is clearly a contemporary one. It is reasonable to project that Vote By Mail will expand to additional states in the coming years.

The spread of the novel coronavirus disease (COVID-19) in America in the spring of 2020 has led to calls for safe, remote voting procedures to limit the spread of COVID-19 and maintain the integrity of elections. The debate around Vote By Mail has vaulted to the forefront of the electoral conversation, with politicians and political groups taking a pro-VBM position that they previously had not advocated (Seitz-Wald \& Kapur 2020). While this conversation has taken on a distinctly partisan nature at the federal level and is showing little sign of movement, several states have already switched their election method, successfully holding primaries by mail that previously would have been conducted in-person (Corasaniti \& Saul, 2020). With Vote By Mail touted by some and derided by others in the political arena, the need for additional study is greater than ever.

\section{Existing Research}

While the transition to mail-based voting system in Oregon and other states has been a topic of academic research, the documented effects of VBM are far from a clear consensus. Early 
studies following Oregon's switch to exclusive mail voting found substantial increases in turnout, giving proponents of the system evidence for its effectiveness (Southwell and Burchett 2000). However, studies which replicated and extended the same research methods found a much smaller impact, with VBM only significantly increasing turnout in local and special elections, where "the relative impact of a minor lowering of the costs of voting would be greatest" (Gronke \& Miller 2012; Southwell 2009). That is to say, voting is inconvenient, and inconvenience is a barrier to voting. That barrier, the cost of voting, is especially difficult to overcome when elections are smaller and garner less attention. These studies suggest that, under such a scenario, the convenience of VBM can make the most difference, while perhaps being a negligible influence otherwise.

A study conducted shortly after Washington adopted a VBM system found that "all-mail elections in Washington State increased the turnout of low-participation citizens more than they did for high-participation citizens" (Gerber, Huber \& Hill, 2013). This potentially significant finding is tempered by a number of studies in Oregon that found the opposite, instead concluding that the "expanded pool of voters will be limited most likely to those already inclined to vote" (Karp \& Banducci, 2000). For reasons that will be discussed in the section below, the potential implications of VBM's effects on low-participation voters is particularly relevant to the Native American Voters, given their demographic characteristics.

All these studies are also impacted by the fact that elections do not take place in a vacuum. For example, the voters in Oregon's standard-format elections prior to the implementation of VBM are not the same voters participating in today's elections. The Oregon of today has almost one million more residents, is significantly more racially diverse, and automatically registers voters through the Department of Motor Vehicles, potentially bringing 
voters less likely to participate into the electorate (Rynard, 2016). This is not to discount the value of research on this subject, but to explain the difficulties of accurately analyzing voter turnout over time. Such difficulties may explain discrepancies in various studies on VBM.

These muddled findings do not paint an obvious picture for predicting the impact of implementing VBM, particularly in regard to specific groups. These discrepancies lend all the more importance to the testing of this hypothesis, not only to see the demographic-specific impact that VBM has on Native American turnout, but also to lend much needed study to the body of VBM literature that currently exists.

\section{Native Americans \& Political Participation}

Native Americans are the most recent group of American citizens to gain the right to vote (McCool, Olson, \& Robinson, 2007). As a voting bloc, the Native American community has a long history of experiencing voter suppression and continue to be subjected to intentional disenfranchisement (Schroedel and Aslanian, 2015). The average person could not be blamed for thinking that the Women's Suffrage Movement might be the most recent expansion of voting rights to a group of American citizens. Similarly, the struggle of African Americans against voter suppression might understandably be the contemporary electoral battlefront the typical individual is familiar with. That is because the plight of Native American voters has been widely ignored by both the media and academia, again emphasizing the urgent need for more research on this topic (Schroedel \& Hart, 2015; Wilkins 2002).

The position of Native Americans, relegated to a lower class, has been reinforced since our nation's founding. The framers of the U.S. Constitution never intended for America's native inhabitants to even be citizens, let alone voters, making the road to Native American 
enfranchisement a long one. The Native American population is demonstrably separated from other groups in both Article One, Section Two, and Article One, Section Eight of the U.S. Constitution. These sections explicitly deny Native Americans living on reservations citizenship (U.S. Const. Art. I). This lack of citizenship meant that even the passage of the Fifteenth Amendment, which prevented denying the right to vote on the basis of race did not apply to the Native American population. It was not until 1924 that Congress granted full U.S. citizenship to Native Americans with the Indian Citizenship Act (McCool, Olson \& Robinson 2007). With the 19th Amendment having been ratified four years prior, Native Americans became "the last group of persons born in the United States to gain citizenship and the franchise" (Schroedel \& Hart, 2015). Despite this congressional action, numerous states continued to deny Native Americans the right to vote, pursuing methods such as literacy tests, denying Native Americans state residency, and statutes echoing the constitution's "Indians not taxed" (McCool, Olson \& Robinson, 2007). While Utah finally became the last state to grant full voting rights to Native Americans in 1962, states sought to suppress the indigenous vote for long after, as was the case with African American voters. Statutes like the federal Voting Rights Act of 1965 and subsequent amendments to it sought to prevent this kind of systematic exclusion against Native Americans, as well as African Americans, particularly in the South (McCool, Olson \& Robinson 2007).

However, despite such federal legislation, state suppression of the Native American Vote continues today. As a result of the rollback of the preclearance requirements of the Voting Rights act of 1965, states have recently had fewer obstacles in the way of enacting laws that restrict voting (Shelby County, Ala. v. Holder). States like South Dakota have gerrymandered legislative seats to minimize the voting power of Native Americans (Schroedel and Aslanian, 2015). Other 
states have crafted statutes that bar Native Americans from being able to cast a ballot at all. North Dakota, for example, altered its existing voter ID law to require a residential address, something Native Americans living on reservations lack in that state (Booker 2020). These de facto forms of disenfranchisement seek to suppress Native American voter turnout and minimize Native American political power.

In addition to discriminatory action by states, the unique positioning of Native American tribes as sovereign nations presents a cultural voting tradition distinctly different from any other. Recognized Native American reservations are sovereign, unlike any other communities with the United States. Some Native American voters hold a sense of patriotism that applies solely to their tribal government (Wilkins 2002). Indigenous voters may prioritize their local elections as well, voting in Tribal elections at higher rates than other elections (Stubben 2006) While these allegiances vary, and Native Americans have by-and-large come to assume more of a role in local, state, and federal politics, the unique position of Native American sovereignty is important to consider when analyzing political participation.

Much like the existing research on VBM, studies on the levels of Native American political participation have varied results. The demographics of Native Americans would suggest a disposition toward lower rates of voter participation. As one researcher noted about the Navajo tribe in Arizona, "they are largely rural, minority populations with lower levels of education and lower incomes than average" (Stubben 2006, 134). This categorization largely describes the Native residents of the Warm Springs reservation in Oregon as well. Of those living within Warm Springs, 9.5 percent have bachelor's degrees or higher, compared to almost 20 percent for Jefferson County, in which the reservation is largely located.. The median income on the reservation is $\$ 43,250,14$ percent lower than the county-wide median of $\$ 50,339$. 
Unemployment for reservation residents is several times that of the Jefferson County workforce overall (U.S. Census).

While there is some variation in the findings of studies on Native American political participation, there are fairly established patterns we can look to for guidance. Some studies have found individual tribes voting at higher rates than other racial groups, including white voters (Stubben 2006), with others finding that there is a historic turnout gap, but that the gap is quickly decreasing (Tracy and Garner, 2014). The academic consensus, however, is that Natives vote at relatively low rates. In fact, an analysis of the 1990 and 1992 elections found that "Native Americans do not vote at the same levels as other groups even when socio-economic levels are controlled" (Peterson 1997, 6), with some estimations that Native American voters participate at a level of 5 to 14 percent lower than other racial and ethnic groups (Wang 2012).

\section{Research Methods}

The research design of this article was consistent with other studies measuring electoral turnout, with election results the primary data for study. The basis for the statistical analysis was the work of Southwell and Burchett (2000), whose methods were replicated by later study. In order to be consistent with the existing discourse community, this study was modeled under the same methodology. That analysis process consists of completing a feasible generalized least squares model (FGLS) using turnout, measured as the proportion of eligible voters casting a ballot in a given election to determine the impact of VBM. The research process involves gathering data regarding election turnout, election method, and types of races on the ballot. The study design I detail here can serve as a template for future scholarly pursuits, filling an important void in the academic literature. 
The demographic and geographical makeup of the Warm Spring Indian Reservation lent itself well to this study. The reservation, governed by the Confederated Tribes of Warm Springs, lies in north-central Oregon, primarily in Jefferson County. The significant population center for the reservation is the community of Warm Springs, which is a census-designated place. This census designation is important to such research, as it offers us detailed demographic information that might not readily exist for other communities. Most importantly, the census bureau's 20142018 American Community Survey 5-Year Estimates put the Native American population at just over 90 percent of the population in the community, making it heterogeneous enough for study (U.S. Census). Additionally, the portion of the reservation that is located in Jefferson county (including Warm Springs, its only significant population center) is designated as its own precinct. This precinct, number fourteen, has been unchanged for decades, making it a consistent point of measure for this study.

By accessing election result records archived in the Jefferson County Clerk, it is possible to see how the Warm Springs community has voted over the years. Jefferson County reports the total ballots cast, as well as the number of registered voters for every election. This is essential, as it allows for a calculation of turnout (the number of ballots cast divided by the number of registered voters). The first step in this research was collecting election results from a wide variety of election types in a large window. In order to follow the structure of previous research of this type (Southwell and Burchett 2000, Gronke and Miller 2012), results from primary elections, general elections, and special elections are required. Additionally, there needs to be a statistically sound number of elections from both prior to VBM implementation, and after. In order to carry out the Variable Coding process laid out by Southwell and Burchett (2000), 
statewide election results will be required for calculations of competitiveness. These must be gathered from the Oregon Secretary of State.

In order to test the working hypothesis that VBM increases Native American turnout in Warm Springs, such a study would need to find that within the data set from Warm Springs, controlling for the nature of the race, VBM elections have a turnout higher than the turnout expected in a non-VBM election.

\section{Research Interruption}

While some initial data collection was undertaken in the fall and winter of 2020 for this paper, the bulk of record collection and analysis was set to be completed during the Spring. In March of 2020 the rapid spread of the novel coronavirus took America, and Oregon, where this research was being carried out, by surprise. In-person record collection would have violated both CDC health guidelines, and Oregon Governor Kate Brown's Executive Order 20-12, commonly known as the "Stay at Home" directive. Attempts to remotely collect data were frustrated by financial limitations, as records request to a County Clerk or the Secretary of State would have resulted in billings for costs far outside the capacity of this project.

This leaves only a small sample of elections for analysis. The dataset is ultimately insufficient for true statistical analysis that is consistent with previous research. Plans were for this study to follow the method of Southwell and Burchett (2000), as had subsequent studies of VBM's impact on Oregon turnout (Gronke and Miller, 2012). Specifically, there are insufficient detailed election results for a calculation of competitiveness, one of several factors required (See Southwell \& Burchett 2000, Appendix, for a detailed explanation of the Variable Coding process). 
Additionally, even a simplistic analysis will be further limited by an inability to compare results to countywide or statewide data. This prevents a determination of whether Warm Springs is being impacted differently than larger regions. This is central to questions of whether VBM impacts varying populations differently. If Native American turnout were increasing at a higher rate than other populations, it would have different implications than if an increase were uniform or nonexistent for Native American voters.

\section{Results}

An analysis of turnout from Warm Springs confirms the demographic assumption that electoral participation would be low for this Native American community. The average participation rate of all 47 surveyed elections comes to just over 25 percent, approximately half that of the County's average of around 50 percent. This confirms that the Warm Springs electorate is not an exception to chronically low Native American turnout. In fact, Warm Springs turnout appears to be lower than what has been found in studies of other Native American communities, with a significantly greater differential between the Native American and nonNative American communities.

Another means of analysis, offering additional insights, is to chart turnout from Warm Springs over time. Figure 1 shows Warm Springs general election turnout in presidential years, with Figure 2 to illustrate midterm elections. A visual inspection of turnout trends in this limited data set does not offer much reinforcement to the assertion that VBM implementation would bolser turnout among Native Americans. This reinforces the findings of Gronke and Miller (2012), who found a similar impact of VBM at the state level. However, this visual representation further illustrates the incompleteness of this dataset. The reliance on only three 
pre-VBM elections allows too much potential for skewed data. For example, we see a similar pattern in both presidential and midterm elections - turnout begins relatively high in our first recorded elections (1988 and 1990 respectively), but quickly declines, followed by an increase after VBM implementation, with turnout declining again recently. Without a larger dataset, it is unclear whether the 1988 and 1992 elections were part of a consistent higher turnout for the reservation or whether they were anomalies now skewing the data, minimizing the detected impact of VBM.

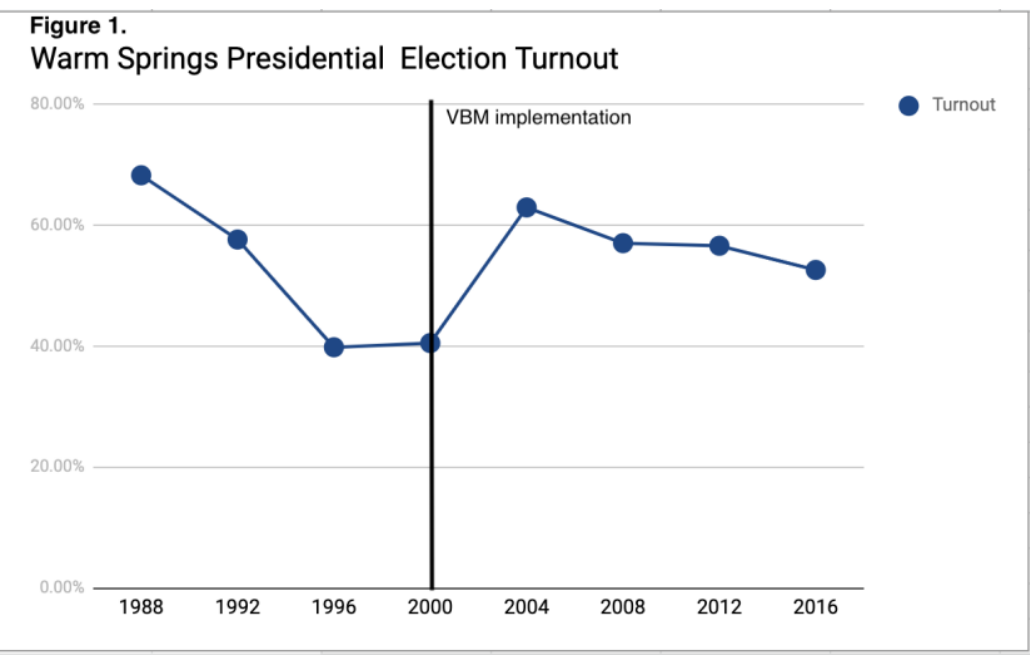

\section{Figure 2.}

Warm Springs Midterm Election Turnout

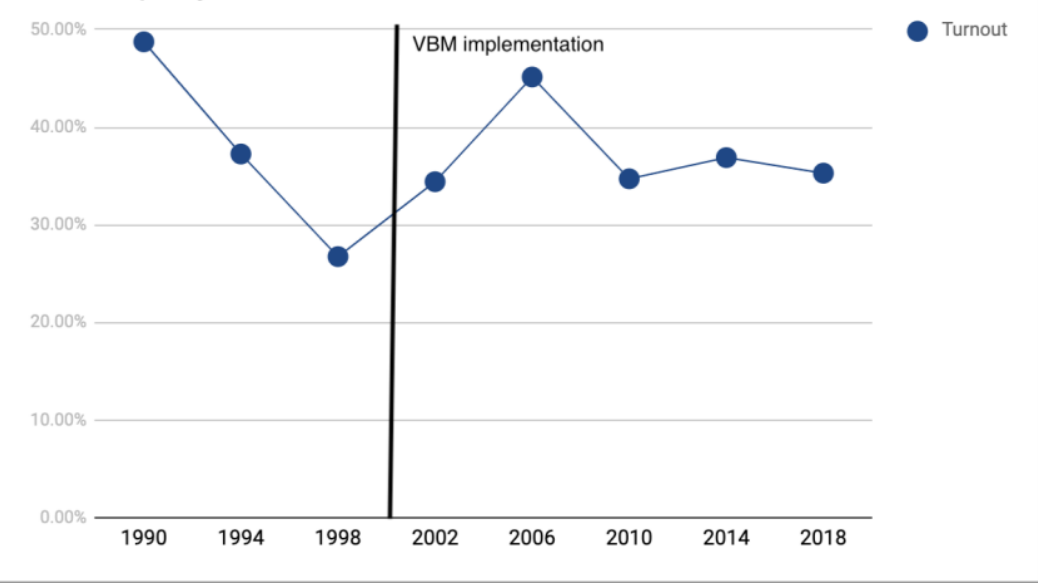


The charts below illustrate turnout from the Warm Springs Reservation both before and after VBM implementation. The comparison is of all Presidential elections averaged. So as to accurately weigh the various elections, the registered voters for all elections in the two comparison groups are totaled, and divided by a total of their votes cast from their respective years. As the table illustrates, the Presidential elections conducted by VBM have an average turnout a little over one and a half percent higher than non-VBM Presidential elections. Prior to VBM implementation we see turnout at 52.88 percent, rising to 54.45 percent after mail voting is adopted.

\begin{tabular}{|l|l|l|}
\hline $\begin{array}{l}\text { Table 1. Average Turnout } \\
\text { in Presidential Elections }\end{array}$ & $\begin{array}{l}\text { Non-VBM } \\
\text { Presidential } \\
(1988, ' 92, ' 96)\end{array}$ & $\begin{array}{l}\text { VBM Presidential } \\
(2000, \text { '04, '08, '12, '16) }\end{array}$ \\
\hline Registered & 2,029 & 4,334 \\
\hline Votes & 1,073 & 2,360 \\
\hline Turnout & $52.88 \%$ & $54.45 \%$ \\
\hline Difference: & & $\mathbf{+ 1 . 5 7 \%}$ \\
\hline
\end{tabular}

Shown below is a similar comparison, using the same methods. Here midterm elections are compared, instead of years with a Presidential election. The average turnout of standard polling-place general elections in midterms years for our data sample is 35.71 percent. Midterm elections conducted with mail voting is found to be 37.26 percent, 1.55 percent higher than the sample of elections with traditional voting. Implementing VBM appears to have increased turnout in Warm Springs by a margin similar to what we see in Presidential years. 


\begin{tabular}{|l|l|l|}
\hline $\begin{array}{l}\text { Table 2. Average } \\
\text { Turnout in Midterm } \\
\text { Elections }\end{array}$ & $\begin{array}{l}\text { Non-VBM } \\
\text { Midterm } \\
(1990, \text { '94, '98) }\end{array}$ & $\begin{array}{l}\text { VBM Midterm } \\
(2002, \text { '06, '10, '14, '18) }\end{array}$ \\
\hline Registered & 2,022 & 4,479 \\
\hline Votes & 722 & 1,669 \\
\hline Turnout & $35.71 \%$ & $37.26 \%$ \\
\hline Difference: & & $\mathbf{+ 1 . 5 5 \%}$ \\
\hline
\end{tabular}

Crucially, one untested hypothesis is the possibility that special elections show the true critical impact of VBM. These elections, either local or statewide, garner significantly lower attention and, as a result, can have abysmal turnout levels. Previous research has found these elections receiving the biggest turnout boost from VBM implementation. It would also have been beneficial to see what increases looked like at the County and State level, to determine if Reservation turnout is increasing more or less in comparison.

\section{Discussion}

While this study may have minimal data for analysis, it has detailed the methodology for a study that can lend greater statistical credibility to its findings. For the purpose of discussion, let us assume that such a study would confirm the results here: If Vote By Mail implementation increases the turnout of Native American voters living on reservations, the increase is negligible. Even if statewide turnout remained unchanged after VBM implementation, a 1.5 percent increase in Native American turnout would do little to remedy the significant gap between Native 
American and non-Native American voters. These results indicate that implementing Vote By Mail does not significantly increase voter turnout for Native Americans. This finding would bolster the argument of researchers such as Karp \& Banducci (2000), who argue that VBM does not disproportionately bring non-traditional voters into the electorate, at least in significant numbers, in general and primary elections. Accordingly, in order to alleviate the chronic low turnout that reservations like Warm Springs are experiencing, it will take more than a shift in electoral method. The purpose of this research was not to determine methods of increasing Native American turnout, but its result suggests that VBM will not suffice for those seeking to increase political participation on reservations.

\section{A Call For Future Study}

The assumption underlying the above discussion is, of course, one that cannot be afforded. The incompleteness of this study means that to this day there exists no sound research on the impact of Vote By Mail on Native American voter turnout. While patterns may have emerged in the minimal analysis allowed, beyond all else it is clear that what is needed is more research. A statistically sound study, in the model of existing respected research, must be carried out not just in Warm Springs, but across reservation communities in Oregon, and other VBM states, such as Washington, Colorado, and Hawaii. The methodology previously described would allow for a uniform research structure, consistent with the existing research. The un-studied topic of VBM's impact on Native American political participation deserves such an approach. 


\section{References}

Oregon Secretary of State. "Oregon Vote-by-Mail”. (n.d.)

https://sos.oregon.gov/elections/Documents/statistics/vote-by-mail-timeline.pdf

Thompson, Daniel M., Jennifer Wu, Jesse Yoder, and Andrew B. Hall. "The Neutral Partisan Effects of Vote-by-Mail: Evidence from County-Level Roll-Outs." Stanford Institute for Economic Policy Research (SIEPR). Working Paper 20-015 (2020): 20-015. Seitz-Walk, Alex., and Sahil Kapur. "Coronavirus has ignited a battle over voting by mail. Here's why it's so controversial.” NBC News. (April 10, 2020) https://www.nbcnews.com/politics/2020-election/coronavirus-has-ignited-battle-overvoting-my-mail-here-s-n1178531

McAvoy, Audrey. "Hawiaii lawmakers pass all-mail elections, automatic recounts." Associated Press News. (May 1, 2019) https://apnews.com/2de69fb1f88c4112b3a6da3625d886aa

Southwell, Priscilla L., and Justin I. Burchett. "The effect of all-mail elections on voter turnout." American Politics Quarterly 28, no. 1 (2000): 72-79.

Gronke, Paul, and Peter Miller. "Voting by mail and turnout in Oregon: Revisiting Southwell and Burchett." American Politics Research 40, no. 6 (2012): 976-997. Gerber, Alan S., Gregory A. Huber, and Seth J. Hill. "Identifying the effect of all-mail elections on turnout: Staggered reform in the evergreen state." Political Science research and methods 1, no. 1 (2013): 91-116.

Karp, Jeffrey A., and Susan A. Banducci. "Going postal: How all-mail elections influence turnout." Political Behavior 22, no. 3 (2000): 223-239. 
Rynard, Gavin. "How to Unlock the Voting Block: Oregon's Sweeping Solution to Poor Voter Turnout: Automatic Registration." U. Miami Int'l \& Comp. L. Rev. 24 (2016): 517. McCool, Daniel, Susan M. Olson, and Jennifer L. Robinson. Native vote: American Indians, the Voting Rights Act, and the right to vote. Cambridge University Press, 2007. Schroedel, Jean, and Artour Aslanian. "Native American Vote Suppression: The Case of South Dakota." Race, Gender \& Class 22, no. 1-2 (2015): 308-323.

Schroedel, Jean, and Ryan Hart. "Vote Dilution and Suppression in Indian Country." Studies in American Political Development 29, no. 1 (2015): 40-67.

Wilkins, David. "Governance within the Navajo Nation: Have democratic traditions taken hold?." Wicazo Sa Review 17, no. 1 (2002): 91-129.

McCool, Daniel, Susan M. Olson, and Jennifer L. Robinson. Native vote: American Indians, the Voting Rights Act, and the right to vote. Cambridge University Press, 2007. Booker, Brakkton. "North Dakota, Native American Tribes Settle Voter ID Lawsuits." National Public Radio. (February 14, 2020)

https://www.npr.org/2020/02/14/806083852/north-dakota-and-native-american-tribes$\underline{\text { settle-voter-id-lawsuits }}$

Stubben, Jerry D. Native Americans and political participation: a reference handbook. ABC-CLIO, 2006.

United States Census Bureau, "Warm Springs Reservation and Off-Reservation Trust Land." My Tribal Area

Skopek, Tracy, and Andrew Garner. "The Disappearing Turnout Gap between Native Americans and Non-Native Americans." American Indian culture and research journal 38, no. 2 (2014): 1-16. 
Peterson, Geoff. "Native American turnout in the 1990 and 1992 elections." American Indian Quarterly 21, no. 2 (1997): 321-331.

Wang, Tova. "Ensuring Access to the ballot for American Indians \& Alaska Natives:

New solutions to strengthen American democracy." New York: Demos. Retrieved July 24 (2012): 2015. 